\title{
Psychological suffering in the daily lives of women who have experienced sexual violence: a phenomenological study ${ }^{a}$
}

\author{
O sofrimento psíquico no cotidiano de mulheres que vivenciaram a violência sexual: estudo \\ fenomenológico
}

\author{
Sufrimiento psíquico cotidiano en mujeres víctimas de la violencia sexual: estudio fenomenológico
}

\author{
Tatiane Herreira Trigueiro ${ }^{1}$ \\ Marcelo Henrique da Silva ${ }^{1}$ \\ Miriam Aparecida Barbosa Merighi ${ }^{1}$ \\ Deíse Moura de Oliveira ${ }^{2}$ \\ Maria Cristina Pinto de Jesus ${ }^{3}$
}

1. University of Sao Paulo.

São Paulo, SP, Brazil.

2. Federal University of Viçosa.

Viçosa, MG, Brazil.

3. Federal University of Juiz de Fora.

Juiz de Fora, MG, Brazil.
Corresponding author:

Miriam Aparecida Barbosa Merighi.

E-mail: merighi@usp.br

Submitted on 10/03/2016.

Accepted on 01/27/2017.

DOI: 10.1590/2177-9465-EAN-2016-0282

\begin{abstract}
Objective: To understand the daily actions of women who have experienced sexual violence. Method: A qualitative study was conducted with 11 women who suffered sexual violence in southern Brazil. Their testimonies were obtained through phenomenological interviews conducted between October 2014 and April 2015. Results: The daily lives of women after suffering sexual violence were permeated by mental distress, translated into fear. This impacted their mental health by limiting their daily lives, especially social activities (work, school, sentimental, and sexual relations). To overcome the consequences of sexual violence, women sought support from family and friends and reintegration into the labor market and course of studies. Conclusion and implications for practice: Individual and group actions providing psychosocial and social support to women in situations of sexual violence are essential to help victims cope with the consequences of this experience.
\end{abstract}

Keywords: Sexual Violence; Mental Health; Psychological Distress; Nursing.

\section{Resumo}

Objetivo: Compreender as ações do cotidiano de mulheres que vivenciaram violência sexual. Método: Pesquisa qualitativa, realizada com 11 mulheres que sofreram violência sexual, no sul do Brasil. Seus depoimentos foram obtidos por meio de entrevista fenomenológica realizada entre outubro de 2014 e abril de 2015. Resultados: Evidenciou-se que o cotidiano de mulheres, após a violência sexual, foi permeado pelo sofrimento psíquico, traduzido pelo medo que impacta sua saúde mental, limitando sua vida, especialmente no desempenho das atividades sociais (trabalho, escola e relações afetivo-sexuais). Para superar as consequências deste tipo de violência sexual, as mulheres buscam apoio de familiares e amigos e a reinserção no mercado de trabalho e na escola. Conclusão e implicações para a prática: Evidencia-se a importância de ações individuais e grupais que confiram apoio psicossocial às mulheres que sofreram violência sexual, objetivando oferecer suporte psicológico e social necessário ao enfrentamento das consequências advindas dessa experiência.

Palavras-chave: Violência Sexual; Saúde Mental; Sofrimento Psíquico; Enfermagem.

\section{Resumen}

Objetivo: Comprender las acciones cotidianas de mujeres víctimas de violencia sexual. Método: Investigación cualitativa realizada con 11 mujeres víctimas de violencia sexual, en el sur de Brasil. Testimonios obtenidos mediante entrevista fenomenológica realizada entre octubre de 2014 y abril de 2015. Resultados: Se evidenció que el día a día de mujeres luego de la violencia sexual estuvo permeado por sufrimiento psíquico, traducido en miedo. Este impacta en su salud mental, limitando su vida, particularmente para desarrollar actividades sociales (trabajo, escuela y relaciones afectivo-sexuales). Para superar la consecuencia de este tipo de violencia sexual, las mujeres buscan apoyo de familiares y amigos y reinserción en el mercado laboral y escolar. Conclusión e implicaciones para la práctica: Se evidencia la importancia de acciones individuales y grupales que brinden apoyo psicosocial a mujeres víctimas de violencia sexual, objetivando brindarles soporte psicológico y social necesario para enfrentar las consecuencias derivadas de esa experiencia.

Palabras clave: Violencia Sexual; Salud Mental; Estrés Psicológico; Enfermería. 


\section{INTRODUCTION}

In all of its forms, violence is a phenomenon that affects women from different social classes, origins, marital status, education levels, race and sexual orientation. It is one of the main forms of human rights violations, affecting women's lives as regards their psychological and physical integrity. Among the different types of violence, rape is the maximum expression of sexual violence. In this study, it is defined as any action in which women are coerced to have sexual relations, against their will. ${ }^{1}$

The literature on sexual violence against women depicts it as a severe social problem that affects mainly young women. A retrospective study conducted in Nigeria included 196 cases of sexual assaults that occurred between 2006 and 2015 and found that most of the victims were women $(93.9 \%)$, under the age of 20 . Vaginal penetration was the most frequent $(87.2 \%)$ form of rape, followed by anal penetration (56\%). Most rapes were committed by someone known to the victim (52\%). The proportion of individuals sexually assaulted in the country increased from $0.2 \%$ in 2006 to $2.0 \%$ in $2015 .{ }^{2}$

The United States Air Force Institute of Technology Medical Center developed a cross-sectional study in which anonymous surveys were conducted with people over the age of 18 and showed that of the 775 participants who had experienced violent situations, 111 were characterized as sexual violence, of which 14 were men and 97, women. These results highlight that sexual trauma can negatively impact people regardless of gender, although women presented more posttraumatic stress disorders. ${ }^{3}$

In Brazil, a study developed in the capital city of the state of Paraná with 1,272 sexual assault victims showed that $53.46 \%$ of them were between 12 and 18 years old and that $94.66 \%$ were women. In over half of the cases, the victim knew the perpetrator $(53.38 \%)$, assaults occurred at the victim's home $(39.30 \%)$ and outside ( $35 \%$ ), at night $(50.33 \%)$ and, in $96.67 \%$ of cases, there was vaginal penetration. ${ }^{4}$

Another Brazilian study conducted in the city of Campina Grande analyzed 886 forensic medical records of sexual violence from the Brazilian Institute of Legal Medical. Rape was confirmed in $32.8 \%$ of the cases. Over a third of the victims were women, with a predominance of adolescents with low education levels. Assailants were known to the women in $84.2 \%$ of the cases. ${ }^{5}$

Regardless of whether or not perpetrators are known to the victim or strangers, sexual violence has the potential to alter the daily lives of women and cause many consequences to their physical, reproductive, psychological and social health, especially among younger individuals. ${ }^{6}$

The literature on sexual violence is expansive and focuses mostly on statistical surveys, ${ }^{3-5}$ which contributes to an epidemiological understanding of the object of study. From a comprehensive approach, studies about the consequences of sexual violence from the point of view of women add value to already existing scientific knowledge.

In light of the above, the following questions guided this investigation: What is the daily life of women who experienced sexual assault like? How do these women expect life to be after having suffered sexual violence? The goal was to understand the daily actions of women who had suffered sexual violence.

Based on the principle that sexual violence is a global public health problem, deepening discussions on the theme based on a phenomenological perspective can unveil important elements to broadening the possibilities of reflection and addressing this problem within the context of health care, teaching and research.

\section{THEORETICAL FRAMEWORK}

Women who have experienced sexual violence form a social group that acts in the world based on intersubjective relationships that are based on existential motives related to the past, present and future. In the present study, these women's actions before the situation of having suffered this type of violence reveals the consequences of this aggressive event in their daily lives, in addition to how they seek to overcome it. This study used the theoretical and philosophical framework of Alfred Schütz phenomenology: social world, intersubjectivity, biographical situation, stock of knowledge, and social action.

The social world is cultural, an interwoven mesh that guides daily actions based on a specific social reality, constituted by people who relate with one another. The founding characteristic of this world is intersubjectivity, which produces social meanings for people immersed in a given reality. Such social meanings are part of the stock of knowledge constructed throughout people's lives. This is composed primarily by early references of the world, which are first built in the family universe. Later, it includes relationships that extend towards the social macrostructure, such as school, work, friendship circles, and others. Experiences that occur within these spaces constantly resignify the social world. ${ }^{7}$

Stocks of knowledge, which are constantly changing, result in taking certain stances in the world, which results in people taking on given biographical situations, i.e., positions occupied in the life-world. ${ }^{7}$ Together, one's stock of knowledge and biographical situation are essential for taking action in this world. Action is the core of social life, for it motivates people, imbued with intentionality, to transform themselves and their social reality. Existential motives are the common thread of social action, woven by past/present experiences (because motive) and by the expectations that individuals launch toward the future (in-order-to motive). ${ }^{7}$

\section{METHOD}

This was a qualitative study grounded in the phenomenological framework of Alfred Schütz' model of social action. 'It was developed at a specialized center for women who experienced situations of sexual violence in the capital of the state of Paraná, southern region of Brazil. Participants were recruited randomly after the researchers consulted the charts of the women who attended this service. Forty-two charts were included according to the following inclusion criteria: women who reported coerced sexual relations, aged 18 years old or older, who received 
treatment in 2013 and the first semester of 2014, with a minimum of six months of outpatient care, and who had not fully adhered to this service. Nonadherence was defined as missing at least one of the follow-up appointments scheduled by the service. Only women who were in sufficient clinical and emotional conditions to provide their testimony were included.

The main researcher called the telephone numbers available in the charts to schedule a meeting with the selected women. Fourteen women were successfully contacted, and of these, three declined participation, finding it hard to relive their experience of sexual assault. Thus, 11 women were interviewed and none of the testimonies were discarded, as all had sufficient meaning to reach the objective of the study. The content of the 11 interviews presented convergence of meaning, reaching theoretical saturation. ${ }^{8}$

The phenomenological interviews followed these guiding questions: Tell me about your life after having experienced sexual violence. After what happened, how do you expect to live with the situation? The interviews lasted an average of 50 minutes and were conducted between October 2014 and April 2015 in a private location, according to the women's preference, (home, school or health service), after signing a free and informed consent form.

The content was organized and analyzed according to the steps suggested by scholars of Alfred Schütz' social phenomenology: ${ }^{9}$ first, the interviews were recorded in MP3 format; testimonies were fully transcribed; the researchers conducted an in-depth reading of the transcribed material; units of meaning were identified and grouped based on converging content, and thematic categories were created that congregated the daily actions of women who had experienced sexual violence. The results were discussed in light of literature on the theme, using the phenomenological assumptions of Alfred Schütz' theory of social action as the common thread.

The study was developed in accordance with the ethical standards set forth by the Brazilian National Health Council's resolution on human research ethics, ${ }^{10}$ and was approved by the research ethics committee of the University of São Paulo School of Nursing, no. 772.012, August 26, 2014, Certificate of Presentation for Ethical Consideration - CAAE no. 31703914.2.0000.5392.

\section{RESULTS}

The 11 women who participated in the study were between the ages of 18 and 27, with a mean age of 20 . All of them had experienced coerced sexual relations and, in most cases, the victim did not know the assailant. Sexual violence had taken place outside and at night.

By understanding how young women victims of sexual violence acted in their daily lives after the aggressive event, the following categories emerged: "Daily life marked by fear" (because motive) and "Overcoming trauma" (in-order-to motive).

\section{Category 1: Daily life marked by fear}

The daily life of the participants was modified by fear that resulted from the assault. The testimonies indicated that the impact of this type of violence transcended the physical dimension, invading the emotional and causing psychological suffering. This then reflected negatively in their performance in routine activities and intersubjective relationships.

Regarding the physical aspects, some women reported that the sexual violence made them afraid of being infected with a sexually transmitted disease (STD):

\section{[...] I was afraid of having been infected by the guy who raped me (M3).}

I was afraid of having some type of disease, and because of HIV, afraid of not being able to have a baby after that (M8).

After the sexual assault, the women reported being afraid of interacting with strangers who reminded them of their assailant.

I walk down the streets looking behind my shoulder with every step. If I see anyone with a baseball cap and a backpack I panic (M1).

[...] I go out on the street and worry, I am fearful. I see someone that looks like the guy and I remember what happened. I'm afraid of someone doing the same thing again (M9).

I'm afraid of the male figure, if I see a man with a similar physique as the guy who did that to me, I'm scared, it can be on the bus, or on the street, I'm scared [...] (M10).

Afraid of being raped again, the women mentioned avoiding sentimental and sexual relationships:

I can't get close to boys, I can't like anyone, I'm afraid that it'll happen again (M2).

[...] I had a boyfriend, not anymore... [...] I broke it off, I'm scared [...] I want to be alone (M5).

I don't let a man get close to me no matter what. The other day, at a bus terminal, a man got close to me and I felt chills in my stomach. I feel the same with my husband or anyone who gets close to me (M7).

The testimonies showed that the fear generated by experiencing sexual violence made women dependent on other people to conduct daily activities in addition to interrupting their education:

Before, I wasn't afraid of anything, and now, after it happened I feel more dependent on others, because I always need someone to go out with. I don't have the autonomy I had before (M10).

I had to stop my driving lessons, I dropped college, because I was afraid of being raped again. [...] the panic was terrible (M1). 
[...] I stopped studying because I was afraid of the guy coming back or everything happening again, I dropped school for a year (M3).

The psychological suffering of women was intensified when they remembered their assault, eliciting feelings such as sadness and anguish. Most participants were not able to call the violent incident by its name:

Every time I remember what happened to me on that day, I feel so sad, I feel like crying (M3.)

If I remember what happened I don't feel like going to work. I start to cry, I feel so much anguish (M5).

[...] soon after it happened, I couldn't talk to people, I didn't eat, didn't sleep, I cried myself to sleep and woke up startled. I feel better now (M11).

\section{Category 2: Overcoming trauma}

The women made reference to the expectation of overcoming the psychological suffering caused by sexual violence. To this end, they sought support from their social network, which consisted of family and friends:

My mother, who is always with me, and my friends help me when I need to leave the house, they give me lots of support (M2).

[...] I tried holding on to the people who are by my side to get through this: my father, my mother, my boyfriend, people who are important to me, when I wasn't feeling well (M10).

My friends helped a lot, they never left me alone. I decided to forget what had happened. I started going out with my friends again (M11).

Work and school were also considered a way of overcoming the trauma of sexual violence:

I started working to lose my fear of people (M5).

I forced myself to get better, I couldn't stay that way forever, that's when I went looking for a technical course (M7).

The possibility of attending an institutional service that supports women victims of sexual violence emerged as one of the contributing factors to overcoming the psychological suffering caused by rape:

What helped the most was the work of the support group and the appointments with the psychologist. It's comforting to know that people are doing something about your case (M8).

The psychological counseling I get from my support group helps me a lot to overcome what I went through (M10).

\section{DISCUSSION}

In this study, fear was a central element (because motive) interfering with the daily lives the women who had experienced sexual violence. It is worth noting that action in the routine world is intentional, as it depends on the stock of knowledge and experiences lived throughout one's life. Thus, the daily actions of these women were permeated by the negative impact of rape in terms of biopsychosocial aspects.

Regarding physical aspects, the women reported fear of STDs. This fear is justified considering that the literature highlights the occurrence of STDs resulting from sexual violence. ${ }^{6,11}$ In Norway, a study with 412 women rape victims with a mean age of 21 detected STDs in $8.5 \%$ of them. Of these, $3.7 \%$ tested positive for hepatitis $\mathrm{B}$ and $\mathrm{C} .{ }^{11}$ In another survey conducted mostly with young Hispanic women from Mexico who had been raped, none of them tested positive for HIV; however, some reported being infected with some form of STD. ${ }^{6}$

Considering the psychosocial dimension, the fear that results from sexual violence interfered in the women's social, sentimental, sexual, work and school relationships. The participants said they needed someone to go outside with them, expressing fear of meeting strangers that would remind them of their assailant, illustrating the repercussion of sexual violence in these women's mental health.

In England, a study relating mental health and rape showed that the women who had suffered this type of violence were 2.5 times more likely to have a history of neurotic disorders than those who had not. Additionally, people who were raped were also significantly more likely to develop drug and alcohol abuse, be admitted in a mental health ward, and present suicide risk. ${ }^{12}$

A descriptive study in English conducted with 142 Hispanic women, most of which were under the age of 18 , showed that after the rape, a great part of them presented symptoms of depression, some considered or had attempted suicide, and others lost their jobs because of the assault. Furthermore, a significant number stated that they felt insecure in their neighborhoods and had moved. ${ }^{6}$

In the city of Recife, Brazil, an investigation with adolescents and young women showed that sexual violence significantly impacted the mental and social health of the participants. The main disorders were phobias, panic disorder, posttraumatic stress disorder, anxiety and depression. ${ }^{13}$

In terms of the fear of establishing sentimental and sexual relationships, a study in the United States associated violence and posttraumatic stress disorders, showing that women who had been sexually assaulted suffered from negative feelings and beliefs, guilt, nightmares, and amnesia, in addition to fear of strangers, which interfered with their sentimental and sexual relationships. ${ }^{3}$ Moreover, the women who were sexually assaulted had more chances of presenting dysmenorrhea, menstrual irregularity, dyspareunia, menorrhagia, amenorrhea, and loss of libido and sexual pleasure. ${ }^{14}$

Feelings of sadness and anguish emerged when participants recalled the assault, which serves as a reminder for health 
professionals to be aware of the consequences of this event for the mental health of women. A study conducted in the Congo highlighted that sexual violence resulted in devastating consequences to the physical and mental health of women, causing damage to victims and, by extension, to their families and communities. These women presented more severe signs and symptoms of psychological disorders when compared to others who had never been victims of this type of violence. Some of the psychological changes included fear, horror, and helplessness. ${ }^{15}$

Alfred Schütz' social phenomenology also refers to expectations (in-order-to motives), which can be applied in the analysis of the daily actions of women who experienced rape. Based on the question of how they intended to live with the fact of having been sexually assaulted, they projected coping strategies to deal with the trauma resulting from this experience. These strategies included seeking support from family and friends, and going back to work and school.

A study in the city of Salvador, Bahia, Brazil, investigated women who suffered intimate partner violence and who belonged to a community supported by nongovernment organizations (NGO) showed that the support of family members, friends and NGOs helped them feel safe, thus contributing to the recovery of their self-esteem and enabling them to resume their lives. This support was considered the key element in coping with the violent situation, whether emotional, spiritual, or material, or even through information received. ${ }^{16}$

The participants in the present study reported that the women's support service had helped them overcome the traumatic consequences of sexual violence. A study that compared the narratives of men and women who suffered sexual assault, which was based on recordings of a sexual assault telephone hotline in the southeast of the United States showed that the service provided support and guidance to the women who felt guilty about the rape and had been discredited by their families, friends and professionals. Men also accessed the hotline to talk about their experiences with sexual assault, as they perceived lack of support from the people closest to them. ${ }^{17}$

The complexity of the situation that involves sexual violence requires attention not only from referral centers, but also from the network of health services. Specialized services should be composed of multiprofessional teams, working from an interdisciplinary framework to recover these women's selfesteem and empower them. Ideally, health teams should consist of doctors, psychologists, nurses, social workers, and, when possible, legal professionals. ${ }^{18}$ Care should include not only technical procedures, but also humanization and embracement to ensure women are heard. Such listening requires that professionals recognize the subjectivity of these women so as to learn about individual care demands. ${ }^{19}$

The Brazilian Ministry of Health's technical standard for preventing and treating disorders related to sexual violence against women and adolescents ${ }^{18}$ does not make a specific mention of nursing actions; however, in referral centers, nurses are the first professional to interact with women in situations of sexual violence. It is worth mentioning that nursing education equips nurses to identify, integrate, coordinate and promote actions to well receive and care for these women at referral centers. ${ }^{20}$

Considering that women victims of violence first contact the health service through nurses, it is important that these professionals be qualified to work with this population. A study conducted with 27 nurses in primary health units in the Brazilian Northeast highlighted that most of these professionals (96.3\%) recognized that their duty was to investigate violence; $22.2 \%$ asked questions about the assault while providing care, $85.1 \%$ had cared for suspected and/or confirmed cases, and $15.8 \%$ had used some type of protocol. But, only $18.5 \%$ felt empowered to deal with cases of sexual violence. The participants reported difficulties in referring cases and recommending treatment, revealing the need for professional training. ${ }^{21}$

The lens of social phenomenology used here to investigate the issue of sexual violence against women enables the recognition of the intersubjectivity inherent to care practices. Such an approach allows health professionals, especially nurses, to become familiar with these women's biographical situation, stock of knowledge and experiences, and the meaning attributed to such experiences. This makes it easier for professionals to propose therapeutic actions to support victims in coping with the assault. ${ }^{22}$

In this context, care provided to women in situations of sexual violence must value rapport, acceptance, autonomy and subjectivity of these women, overcoming the biologicistic approach, encouraging co-responsibility, guided by the principle of comprehensiveness. ${ }^{23}$

Limitations of this study include that it was conducted by one group of women cared for at a specialized service for sexual violence in a given Brazilian municipality, which does not allow for its results to be generalized. However, the phenomenological perspective values the experience of these women and therefore shows subjective aspects related to psychological suffering due to sexual violence and the importance of overcoming the marks left by this type of violence, which refer to the need for a professional approach centered on these women's mental health.

\section{CONCLUSIONS AND IMPLICATIONS FOR PRACTICE}

By better understanding the daily lives of women who had experienced sexual violence, this study demonstrated their psychological suffering, translated into fear of being raped again, of having been infected with STDs, and of maintaining social, sentimental and sexual relationships. This fear impacted their mental health, restricting their lives at the biopsychosocial levels. To overcome the consequences of sexual violence, they sought the support from their families and friends and reinsertion into the labor market and school.

The findings of this study, grounded in the principles of Alfred Schütz' social phenomenology, can inform professionals who work in different healthcare contexts on how to approach women who have experienced sexual violence. The subjective and social 
aspects implied in this experience must be understood and taken into account by nurses and other health professionals who care for these women in the daily routine of healthcare services.

It is believed that such understanding provides access to the experience of women who have been victims of sexual violence, based on the subjective feminine universe (with emphasis to the consequences produced in the biopsychosocial social context), must be considered in order to plan and provide comprehensive care. This type of care is based on shared responsibility and establishing bonds of trust between these women and healthcare professionals.

Due to the emergency of the psychological suffering experienced by the studied group, individual and group actions that provide psychosocial support to women in situations of sexual violence is of utmost importance. These actions must provide them with the necessary psychological and social support so that they can cope with the consequences of this experience.

\section{REFERENCES}

1. Ministério da Justiça e Cidadania (BR). Secretaria Especial de Políticas para as mulheres. Política Nacional de Enfrentamento à violência contra as mulheres. Brasília (DF); 2011. Available from: http://www.spm.gov. $\mathrm{br} /$ sobre/publicacoes/publicacoes/2011/politica-nacional

2. Ezechi OC, Musa ZA, David NA, Wapmuk AE, Gbajabiamila TA, Idigbe $\mathrm{IE}$, et al. Trends and patterns of sexual assaults in Lagos south-western Nigeria. Pan Afr Med J [Internet]. 2016 Jul [cited 2016 Nov 28];20(24):261. Available from: https://www.ncbi.nlm.nih.gov/pmc/articles/PMC5075452/ pdf/PAMJ-24-261.pdf. doi: 10.11604/pamj.2016.24.261.9172

3. Guina J, Nahhas RW, Kawalec K, Farnsworth S. Are Gender Differences in DSM-5 PTSD Symptomatology Explained by Sexual Trauma? J Interpers Violence [Internet]. 2016 Nov [cited 2016 Nov 28]; 0886260516677290. Available from: http://journals.sagepub.com/doi/ pdf/10.1177/0886260516677290. doi: 10.1177/0886260516677290

4. Trigueiro TH, Merighi MAB, Medeiros ARP, Ribeiro CEL, Mata NDS, Jesus MCP.Victims of sexual violence attended in a specialized service. Cogitare Enferm [Internet]. 2015 Jun [cited 2016 Sep 15]; 20(2):249-54. Available from: http://revistas.ufpr.br/cogitare/article/view/40355/25510. http://dx.doi.org/10.5380/ce.v20i2.40355

5. Souto RQ, Araújo FKDC, Xavier AFC, Cavalcanti AL. Rape against Brazilian Women: Characteristics of Victims and Sex Offenders. Iran J Public Health [Internet]. 2015 Dec [cited 2016 Nov 28]; 44(12):16139. Available from: https://www.ncbi.nlm.nih.gov/pmc/articles/ PMC4724734/pdf/lJPH-44-1613.pdf

6. Basile KC, Smith SG, Walters ML, Fowler DN, Hawk K, Hamburger ME. Sexual Violence Victimization and Associations with Health in a Community Sample of Hispanic Women. J Ethn Cult Divers Soc Work [Internet]. 2015; Dec [cited 2016 Nov 28]; 24(1):1-17. Available from: https://www.ncbi.nlm.nih.gov/pmc/articles/PMC4701051/pdf/ nihms745614.pdf. doi: 10.1080/15313204.2014.964441

7. Schütz A. Sobre fenomenologia e relações sociais. Petrópolis: Vozes; 2012. 357p.

8. Fontanella BJB, Luchesi BM, Saidel MGB, Ricas J, Turato EB, Melo DG. Amostragem em pesquisas qualitativas: proposta de procedimentos para constatar saturação teórica. Cad Saúde Pública [Internet]. 2011 Feb [cited 2016 Sep 16]; 27(2):388-94. Available from: http://www.scielo. br/pdf/csp/v27n2/20.pdf. doi: 10.1590/S0102-311X2011000200020

9. Jesus MCP, Capalbo C, Merighi MAB, Oliveira DM, Tocantins FR, Rodrigues BMD, et al. The social phenomenology of Alfred Schütz and its contribution for the nursing. Rev Esc Enferm USP [Internet] 2013 Jun [cited 2016 Sep 16]; 47(3):728-33. Available from: http:// www.scielo.br/pdf/reeusp/v47n3/en_0080-6234-reeusp-47-3-00736. pdf. doi: 10.1590/S0080-623420130000300030
10. Ministério da Saúde (BR). Conselho Nacional de Saúde. Resolução no 466, de 12 de dezembro de 2012. Dispõe sobre pesquisa envolvendo humanos. Brasília (DF): Conselho Nacional de Saúde; 2012.

11. Hagemann CT, Nordbø SA, Myhre AK, Ormstad K, Schei B. Sexually transmitted infections among women attending a Norwegian Sexual Assault Centre. Sex Transm Infect [Internet]. 2014 Feb [cited 2016 Sep 16]; 90(4):283-9. Available from: http:// sti.bmj.com/content/90/4/283. doi: 10.1136/sextrans-2013-051328

12. Brooker $\mathrm{C}$, Tocque K. Mental health risk factors in sexual assault: What should Sexual Assault Referral Centre staff be aware of? J Forensic Leg Med [Internet]. 2016 May [cited 2016 Nov 28]; 40:28-33. Available from: http://www.jflmjournal.org/article/S1752928X(16)00038-X/pdf. doi: 10.1016/j.jflm.2016.01.028

13. . Procópio EVP, Feliciano CG, Silva KVP, Katz CRT. Representação social da violência sexual e sua relação com a adesão ao protocolo de quimioprofilaxia do HIV em mulheres jovens e adolescentes. Ciênc Saúde Coletiva [Internet]. 2014 Jun [cited 2016 Nov 5]; 19(6):1961-9. Available from: http://www.scielo.br/pdf/csc/ v19n6/1413-8123-csc-19-06-01961.pdf. doi: 10.1590/141381232014196.08382013

14. Di Giacomo E, Alamia A, Cicolari F, Cimolai V, Clerici M. Sexual abuse in adulthood: when psychic and somatic sufference blends. Riv Psichiatr [Internet]. 2014 [cited 2016 Nov 28]; 49(4):172-9. Available from: http://www.rivistadipsichiatria.it/r.php?v=1600\&a $=17454 \& \mathrm{I}=25868 \& \mathrm{f}=$ allegati/01600_2014_04/fulltext/04-Di\%20 Giacomo\%20172-179.pdf. doi: 10.1708/1600.17454

15. Dossa NI, Zunzunegui MV, Hatem M, Fraser WD. Mental Health Disorders Among Women Victims of Conflict-Related Sexual Violence in the Democratic Republic of Congo. J Interpers Violence [Internet]. 2015 Aug [cited 2016 Sep 16]; 30(13):2199-220. Available from: http://journals.sagepub.com/doi/ full/10.1177/0886260514552447. doi: 10.1177/0886260514552447

16. Gomes NP, Diniz NMF, Reis LA, Erdmann AL. The social network for confronting conjugal violence: representations of women who experience this health issue. Texto Contexto Enferm. [Internet]. 2015 Jun [cited 2016 Sep 16]; 24(2):316-24. Available from: http://www.scielo.br/scielo.php?script=sci_ar ttext\&pid=S0104-07072015000200316. doi: 10.1590/010407072015002140012

17. Young SM, Pruett JA, Colvin ML. Comparing Help-Seeking Behavior of Male and Female Survivors of Sexual Assault: A Content Analysis of a Hotline. Sex Abuse [Internet]. 2016 Nov [cited 2016 Nov 28]. Available from: http://journals. sagepub.com/doi/pdf/10.1177/1079063216677785. doi: 10.1177/1079063216677785

18. Ministério da Saúde (BR). Prevenção e tratamento dos agravos resultantes da violência sexual contra mulheres e adolescentes: Norma Técnica. 3ª ed. Brasília (DF): Ministério da Saúde; 2012.

19. Barros LA, Albuquerque MCS, Gomes NP, Riscado JLS, Araújo BRO, Magalhães JRF. The (un)receptive experiences of female rape victims who seek healthcare services. Rev Esc Enferm USP [Internet]. 2015 Abr [cited 2016 Nov 26]; 49(2):193-200. Available from: http://www.scielo.br/pdf/reeusp/ v49n2/0080-6234-reeusp-49-02-0193.pdf. doi: 10.1590/S0080623420150000200002

20. Cortes LF, Padoin SMM. Intentionality of the action of caring for women in situations of violence: contributions to Nursing and Health. Esc Anna Nery [Internet]. 2016 Aug [cited 2016 Sep 19]; 20(4):e20160083. Available from: http://www.scielo. br/pdf/ean/v20n4/en_1414-8145-ean-20-04-20160083.pdf. doi: 10.5935/1414-8145.20160083

21. Baptista RS, Chaves OBBM, França ISX, Sousa FS, Oliveira MG, Leite CCS. Violência sexual contra mulheres: a prática de enfermeiros. Rev Rene [Internet]. 2015 Mar-Apr [cited 2016 Sep 16]; 16(2):210-7. Available from: http://www.periodicos.ufc.br/ index.php/rene/article/viewFile/2710/2094. doi: 10.15253/21756783.2015000200010 
22. Freitas RJM, Moura NA, Monteiro ARM. Violence against children/ adolescents in psychic suffering and nursing care: reflections of social phenomenology. Rev Gaúcha Enferm [Internet]. 2016 Apr [cited 2016 Nov 2]; 37(1):e52887. Available from: http://www.scielo. br/pdf/rgenf/v37n1/en_0102-6933-rgenf-1983-144720160152887. pdf. doi: 10.1590/1983-1447.2016.01.52887
23. Guzzo PC, Costa MC, Silva EB, Jahn AC. Healthcare practices for users suffering from violence: from invisibility to comprehensive (un)care. Rev Gaúcha Enferm [Internet]. 2014 [cited 2016 Nov 2]; 35(2):100-5. Available from: http://www.scielo.br/pdf/rgenf/ v35n2/1983-1447-rgenf-35-02-00100.pdf. doi: 10.1590/19831447.2014.02.40451

a Article extracted from the thesis: "Non-adherence to outpatient follow-up by women who have experienced sexual violence: phenomenological approach", held at the University of São Paulo School of Nursing, under the guidance of Full Professor Miriam Aparecida Barbosa Merighi. 